\title{
Socioemotional Wealth and Firms' Control: Evidence from Malaysian Chinese Owned Companies
}

\author{
Chin Fei Goh, ${ }^{*}$ Amran Rasli, ${ }^{a}$ Owee Kowang Tan, and Sang Long Chor \\ ${ }^{2}$ Faculty of Management, Universiti Teknologi Malaysia \\ ${ }^{\mathrm{b}}$ International Business School, Universiti Teknologi Malaysia
}

\begin{abstract}
This paper explores how the preservation of socioemotional wealth can be manifested in the control and corporate governance of Malaysian Chinese firms. Using panel data from the Industrial Products index of the Bursa Malaysia (the Malaysian stock exchange) during 2003-2006, we show that the ingrained 'life-raft values' among overseas Chinese entrepreneurs can be associated with the preservation of their socioemotional wealth, and thus they prioritize control over their firms. Additionally, we confirm the monitoring role of non-dominant large shareholders in reducing the families' influence in managing and enhancing their firms' performance. Specifically, control contestability exercised by the non-dominant large shareholders mediates the relationship between a family's involvement in management and their firm's performance.
\end{abstract}

Abstrak: Makalah ini membahas bagaimana pelestarian kekayaan sosioemosional dapat diwujudkan dalam kontrol dan tata kelola perusahaan dari perusahaan China Malaysia. Menggunakan data panel dari indeks Industri Produk dari Bursa Malaysia selama 2003-2006, menunjukkan bahwa mendarah-daging 'hidupnilai rakit' antara pengusaha Cina di luar negeri dapat dikaitkan dengan pelestarian kekayaan sosioemosional mereka, sehingga mereka memprioritaskan kontrol atas perusahaan mereka. Selain itu, kami mengkonfirmasi peran monitoring pemegang saham besar non-dominan dalam mengurangi kinerja keluarga 'pengaruh dalam mengelola dan meningkatkan perusahaan mereka.' Secara khusus, kontrol contestability dilakukan oleh pemegang saham besar non-dominan yang memediasi hubungan antara keterlibatan keluarga dalam manajemen dan kinerja perusahaan mereka.

Keywords: corporate governance; family firms; large shareholders; life-raft values; socioemotional wealth

JEL classification: $\mathrm{G} 30, \mathrm{G} 32$

* Corresponding author's e-mail:gcfei@utm.my 


\section{Introduction}

A contention of the socioemotional wealth concept is that family firms rely on a pivotal reference point, namely socioemotional wealth, in decision-making (GómezMejía et al. 2007; Gomez-Mejia et al. 2011). In this regard, family owners view their business enterprises as a means to achieve family affective needs in which the preservation of the family's welfare and emotional satisfaction becomes the main objective of the family businesses. That is, the non-economic dimension of socioemotional wealth pre-empts profit maximization as the ultimate objective of the family businesses.

The researchers in the areas of family businesses generally acknowledge that family firms are distinctive business entities because they are not exclusively driven by economic objectives (Sirmon and Hitt 2003; Gomez-Mejia et al. 2011; Berrone et al. 2012; Siebels and zu Knyphausen-Aufseß 2012). While the preservation of socioemotional wealth may not become the pivotal point of decision-making in family firms, familial orientations and agendas tend to be reflected in the owner-managed firms (Miller et al. 2011). In other words, owner-managed firms tend to prioritize control of the firm to protect their socioemotional wealth. By contrast, family firms with a separation of ownership and control tend to be more entrepreneurially oriented. In this regard, there is a knowledge gap in understanding the reaction of family owners to avoiding losing control of their firms due to the threat of non-dominant shareholders (Schulze and Gedajlovic 2010).

Most recent studies into overseas ethnic-Chinese businesses have mainly focused on 'familism' in the business' structure and Chinese culture (Wijaya 2008; Carney and Gedajlovic 2002; Bertrand and Schoar 2006).
Chinese-ethnic business enterprises generally prioritize kinship ties in raising capital, hiring managers and adopt a family-centric management style. Yet, despite the extensive literature on overseas Chinese businesses, very little research has directly examined the interaction between family owners and nondominant large shareholders, which in turn may affect the firms' performance. This knowledge void is interesting because the presence of multiple large shareholders in an ownership structure can be a powerful coalition to monitor and exercise control contestability over family owners in family firms (Attig et al. 2009; Gutierrez and Pombo 2009; Goh et al. 2014).

Thus, this study intends to fill the knowledge void by examining the preservation of socioemotional wealth in family firms with regard to the firms' control in overseas Chinese family firms. We examine how family owners react to the control contestability exercised by non-dominant large shareholders. We propose that overseas Chinese family firms with the ingrained 'life-raft values' of Chinese family businesses can be explained by the preservation of the socioemotional wealth. To the best of our knowledge, this study represents the first attempt to bridge the gap between the socioemotional wealth and 'life-raft values' in Chinese family businesses.

This paper focus on overseas Chinese in Malaysia (henceforth Malaysian Chinese) because we considered that the institutional context is an important determinant in shaping the culture and management style for overseas Chinese businesses. In general, the Malaysian economic system is regarded as a state-directed economy. Malaysian Chinese entrepreneurs are discontent with the corporate ownership restrictions imposed by the New Economic Policy (NEP) in Malaysia 
(Gomez 2009). In addition, the establishment of state-owned enterprises under the NEP has threatened the dominant ownership position of Malaysian Chinese entrepreneurs in the corporate sectors. Thus, this hostile business environment provides an excellent empirical setting to examine the preservation of socioemotional welfare among Malaysian Chinese entrepreneurs. Specifically, we chose the Malaysian Chinese businesses in the manufacturing sector for two reasons. Firstly, we argue that capital intensive manufacturing firms may induce close monitoring or intervention by their non-dominant large shareholders to prevent the appropriation of the firms' assets by the family owners. Secondly, the NEP has restricted the Malaysian Chinese entrepreneurs in their attempts to increase their ownership in newly established manufacturing firms (Gomez 2009).

The rest of the paper is organized as follows. The next section reviews the relevant literature and develops the hypotheses. Section 3 discusses the dataset and the solution methods. The main results are presented in Section 4. Section 5 provides a conclusion.

\section{Literature Review and Hypotheses Development}

\section{Preservation of Socioemotional wealth in Family Firms}

Family firms are widely recognized as unique business entities because they are not exclusively driven by economic objectives (Dyer 2003; Gomez-Mejia et al. 2011). In the view of the uniqueness of family firms, Gómez-Mejía et al. (2007) proposed a Socioemotional Wealth (SEW) framework to explain the myths of decision-making in family firms. The main assumption of SEW is that a family firm relies on its perceived prime reference point for any major decision-making. SEW explains that the family owners emphasize the family's welfare and emotional attachments over economic utility in family firms. Stated differently, preservation of the SEW can be interpreted as the preservation of the family's utility function that includes the family's welfare and emotional attachments. Thus, the risk profile of the family owners is contingent upon protecting their socioemotional wealth.

\section{Family Involvement in Management and Firm Performance}

In general, family owners can influence business strategies and decision-making because they are the dominant controlling shareholders in the firms. Nevertheless, family influences may differ across family firms due to the different degrees of family involvement in management (Shanker and Astrachan 1996) and thus the family's emotional components are also not uniformly identical. Berrone et al. (2012) explain that family firms with strong influences and the families' involvement in management tend to prioritize their socioemotional wealth. This can be seen from the family's involvement in management, through the appointment of the family Chief Executive Officer (CEO) in family firms. This is also consistent with the view that family involvement in management tends to reflect familial orientations and agendas in family firms (Miller et al. 2011).

Family involvement in management often leads to family owners having strong control over the firm through two sources of power. Firstly, the appointment of family CEOs gives ultimate control to the family owners of the firms' decision-making. Be- 
cause the $\mathrm{CEO}$ is the highest formal position within the hierarchical organization, family CEOs are less likely to rely on support from other members of the management team in controlling the firm (Finkelstein 1992). Additionally, the CEO (or management) is better positioned to have knowledge and control of the firm's informational material (Mace 1972). Thus, family CEOs can exert a significant influence over outside directors who rely on the disclosed information to perform any independent monitoring. Another example is that the family owners may opt for a CEOs duality leadership structure, through the appointment of family members to be the CEO and the chairman of the board of directors to fully control the firm and its management (Adams, Hermalin, and Weisbach 2010).

Secondly, family owners can enhance their control of the firm through their dominant ownership position in the ownership structure. The ownership power defined here is the power delegated to managers to manage the business on behalf of the shareholders. In family firms, the structural power of family managers is enhanced by their ownership power and thus they have a strong influence over the firms' decision-making (Daily and Johnson 1997). Furthermore, high ownership power enables family CEOs to attenuate the monitoring role of the board of directors by reducing the board's independence (Finkelstein 1992). In this regard, Jones et al. (2008) explain that family firms are reluctant to lose control of the firm in order to preserve the SEW; therefore, family firms generally have higher trust and relational ties with affiliated directors and are unlikely to cede control to the board.

As noted above, family owners derive their strong control from their structural and ownership powers. The power in the firm's structure is, therefore, polarized when the family owners become involved in management. However, excessive power could facilitate the expropriation of minority shareholders by family owners who prioritize the SEW's preservation, i.e., firm resources are utilized to safeguard family interests rather than maximize the firm's value. This is also known as Principal-Principal (PP) conflicts (Jiang and Peng 2011). In this regard, firms' assets and resources are subject to appropriation by the family owners. For example, their dominant position enables the family owners to determine profit sharing schemes and the business' structures to serve their personal interests (Claessens and Fan 2002). This is known as 'tunnelling resources' and can be exhibited through transfer pricing, unfairly high compensation packages for management, engaging in non-arms length transactions (La Porta et al. 2002) and paying out high dividends (Chen et al. 2009). In turn, the stock market may discount the market value of family firms because of heightened concerns when the controlling shareholders are exposed to more incentives to expropriate minority shareholders (Young et al. 2008).

In line with the previous arguments, prior empirical studies have shown that the expropriation of minority shareholders is prevalent in emerging economies (Wahab et al. 2011; Chen et al. 2009; Liew 2007). For instance, Chen et al. (2009) show that controlling shareholders utilize money raised during the initial public offering and rights issue to pay dividends based on self interest objectives in China. Similar evidence is also found in Malaysia. Wahab et al. (2011) discovered that announcements of related party transactions by firms had discounted these firms' market performance in Malaysia. Similarly, Liew (2007) discovered that corporate practitioners perceived that the expropriation 
of the minority shareholders by the controlling shareholders was prevalent in Malaysia. The weak enforcement of the rules and regulations in Malaysia also increases the risk of the expropriations of minority shareholders by the controlling shareholders (Porta et al. 1998; Friedman et al. 2003). The corresponding testable hypothesis is thus:

\section{$H_{i}$ : Family involvement in management is negatively related to the firms' performance.}

\section{Preservation of Socioemotional Wealth and Control Contestability}

Large control contestability stemming from the non-dominant large shareholders in the ownership structure signifies a threat to the family owners of losing control of the firm. Although the corporate takeover mechanism is generally restricted by high ownership concentrations in emerging economies (Porta et al. 1999), we suggest that corporate takeovers may be feasible if the non-family large shareholders have a higher proportion of the shares. The rationale is that the non-family large shareholders do not need to purchase shares aggressively in a limited supply market (Burkart et al. 1998). Stated differently, a group of large shareholders can form a coalition to initiate a takeover of a firm at a lower cost. For example, in Malaysia, the Business Times (2013) reported that a coalition of four large shareholders of Bright Packing Berhad managed to remove the dominant family shareholders, who owned about 30.58 percent of the voting rights, from the board of directors.

In Malaysia, Malaysian Chinese entrepreneurs have been discriminated against since the implementation of the NEP in 1971. The NEP is an affirmative action policy to restructure corporate ownership so that Bumiputera, non-Bumiputera and foreign in- vestors can hold 30 percent, 40 percent and 30 percent corporate ownership respectively (Yasuda 1991). The Bumiputera in the NEP policy mainly refers to the ethnic-Malay group in Malaysia (Tam and Tan 2007). To do so, the Malaysian government enacted the Industrial Coordination Act of 1975 (ICA 1975) to increase the Bumiputera ownership in the corporate sector by restricting nonBumiputera and foreign equity ownership in new manufacturing establishments (Yeung 1999). Needless to say, Malaysia Chinese entrepreneurs are fearful of losing corporate ownership (or control) because the NEP policy is hostile towards non-Bumiputera ethnic groups. Thus, Malaysian Chinese entrepreneurs must resort to family members in their business operations according to their ingrained 'life-raft values' (Carney and Gedajlovic 2002). In turn, control over their firms becomes a means for Malaysian Chinese entrepreneurs to achieve security in a hostile environment (Kao 1993). These arguments centre on the overseas Chinese entrepreneurs view of the business enterprise as a 'familial life raft' and they have a strong preference to sustain the status quo of the family firms through maintaining control over the firms. Stated differently, the preservation of their control of the firms becomes the pivotal point in Malaysian Chinese family businesses and thus they are reluctant to liquidate their equity shares. In turn, the voting rights of the non-dominant large shareholders are restricted since it is expensive to acquire more of the limited freely floating shares on the open market.

Putting these ideas together, we believe that control rights are the single most important instrument for family owners to shield them from the threats from other large shareholders. In other words, control over the firm is the pivotal point for Malaysian Chinese 
owner-managed firms to protect their socioemotional wealth. Similar arguments can be detected in recent empirical studies that show that family owners incorporate emotional values into their control over their firms (Zellweger et al. 2012; Gómez-Mejía et al. 2007). For instance, Gómez-Mejía et al. (2007) investigated family choices about control in 1237 Spanish family firms with olive oil mills for a 53-year sample period. They showed that the higher degree of family involvement in the ownership and control signified greater SEW attachments among the family owners. Thus, the Spanish family owners viewed the preservation of their SEW to be a prime reference point in their business operations and they were willing to accept lower levels of performance from their firms, and a higher probability of their businesses failing, to preserve their control over their firms. In a similar vein, Zellweger et al. (2012) provided corroborating evidence by showing that the family owners perceived their equity shares to have a higher fair value compared to the market's perceived fair value in Switzerland and Germany. Zellweger et al. (2012) concluded that family owners, who intended to have transgenerational control, asked for significant premiums on their equity shares. Based on the above arguments, we propose the following hypothesis:

$H_{2}$ : Family involvement in management is negatively related to the control contestability in the ownership structure stemming from non-dominant large shareholders.

Thus far, we have argued that the preservation of socioemotional wealth translates into lower control contestability in the ownership structure. Nevertheless, the control contestability exercised by non-dominant large shareholders can enhance corporate governance in family firms. An implication of this line of reasoning is that family orientation in family-controlled firms may be suppressed by the monitoring of non-dominant large shareholders. The intervention of nondominant large shareholders in the family's agenda can be manifested in two ways.

First, the presence of large shareholders may actively engage in firms' monitoring with lower costs (Shleifer and Vishny 1986). Previous empirical studies have shown institutional investors can influence the corporate investment decisions in technology-based firms (Le et al. 2006; Kor 2006). For example, Le et al. (2006) showed that institutional ownership positively moderated the relationship between a firm's R\&D investment and the firm's performance. This implies all types of firms are likely to experience stringent monitoring and intervention because institutional investors are equipped with oversight skills (Le et al. 2006).

Second, large shareholders may intervene in designing the compensation packages for family managers. Gomez-Mejia et al. (2003) showed that compensation packages for family firms differed to those of non-family firms in the United States. Specifically, family owners are reluctant to issue stock options to nonfamily executives to avoid diluting control of the firm. The compensation package for family CEOs is also designed to be insulated from systematic business risks. This can be interpreted as family owners intending to protect family managers in family-controlled firms. Meanwhile, Gomez-Mejia et al. (2003) also showed that the presence of institutional investors discouraged the issuance of stocks for family CEOs to prevent family owners strengthening their controlling position. Thus, familial orientations in compensation packages were restricted by the monitoring of large shareholders. 
Based on these explanations, our view is that control contestability in the ownership structure enhances corporate governance and thus enhances the performance of family firms. Thus, the control contestability will subsequently mediate the relationship between family involvement in management and the firms' performance. We submit the following hypothesis.

$H_{3}$ : The control contestability in the ownership structure stemming from non-dominant large sharebolders mediates the relationship between the family's involvement in management and the firm's performance.

\section{Methods}

\section{Sample and Data Collection}

Our dataset covers 112 Malaysian Chinese firms listed in the Industrial Products index on the Bursa Malaysia (the Malaysian stock exchange). The selected firms are classified as manufacturing firms in the industrial products industry, based on the industry's definition by Bursa Malaysia. We obtained ownership information, corporate governance; and family relations for substantial shareholders and directors from the annual reports. Financial data and market equity prices were collected from Datastream.

To identify Malaysian Chinese family firms, we relied on a 10 percent cut-off of voting rights (Claessens et al. 2002) as the threshold to identify the ultimate controlling shareholders. We regarded ownership by all the family members as a single controlling entity (Claessens et al. 2002). Because multiple controlling shareholders may be present in the ownership structure, we only selected Malaysian Chinese family firms where the Chinese family owners appeared to be the largest shareholders.
We purposely chose the sample period from 2003 to 2006 because it was a stable economic period, to reduce potential bias in the market-based performance measures ( $\mathrm{He}$ and Wang 2009). The rationale is that market investors may be irrational when economic shocks unfold, such as during a financial crisis, and subsequently depress the market equity prices and cause unstable performance by firms (Saffi and Sigurdsson 2011). In total, our sample comprises of 448 firmyear observations over the four years.

Finaly, our chosen sample period offered a setting where governance variables could be assumed to be exogenous with respect to firms' performance. Such a sample period is important because the rapidly changing ownership patterns may lead to reverse causality (Claessens et al. 2002; Gassen 2014). The ownership structure in Malaysia has largely remained unchanged between 2000 and 2008 (Carney and Child 2013; Claessens et al. 2002), so we can rule out the reverse causality of governance variables from 2003 to 2006 in this study.

\section{Measurements}

A Partial Least Square-Structural Equation Modelling (PLS-SEM) was used to perform the statistical tests for the proposed hypotheses in this study. The structural equation modelling was appropriate because some corporate governance and financial variables were difficult to observe directly (Azim 2012; Lin 2005; Johnson and Greening 1999). For example, we used a two-item construct to measure control contestability, family involvement in management, capital structure, firms' investment and firms' size in this study and thus mitigating the measurement errors problems. We used SmartPLS 2.0 in the model's estimation and results evaluation (Ringle et al. 2005). We followed the two step 
approach for reporting the PLS-SEM results to assess the measurement model and the structural model (Chin 2010).

In this study, a single-item measure is used for several constructs including firms' performance, ownership concentration and board independence. This single-item construct had been utilized in prior corporate governance studies that employed the PLS-SEM method when there were no latent variables available (Berthelot et al. 2012; Li et al. 2006). Diamantopoulos et al. (2012) suggest that the single-item construct (or concrete construct) should be used when there is only one, if not holistically one, attribute being represented. In this regard, the attribute of the variables such as firms' performance, ownership concentration and board independence is concrete and can be measured by the single-item construct.

First, the firm's performance construct was the market-to-book ratio. The firm's market value was the market value of the common stock and the book value of preferred shares and debt, whereas the book value was the total assets. Claessens et al. (2002) and Young et al. (2008) suggested that the market-based valuation was appropriate to measure the firm's performance in emerging economies because market investors would discount the fair value of the shareholdings based on the concerns of principal-to-principal conflicts.

Second, ownership concentration was the voting rights of the largest shareholder in the selected Malaysian Chinese firms (Liew et al. 2011; Grosfeld 2009; Tam and Tan 2007). That was, the ownership concentration was also the voting rights owned by the Malaysian Chinese family owners in their family firms. We included ownership concentration because it was regarded as an incentive for shareholders to engage in monitoring the firm and its management.
Third, board independence was the proportion of independent directors on the board. The independent directors were included because they were expected to independently monitor the firm's management (Adams et al. 2010).

Several multiple item constructs were regarded as latent variables in this study. First, control contestability was measured by two items that reflected the construct: (i) the ratio of the voting rights of the second largest shareholder to the voting rights of the largest shareholder, and (ii) the ratio of the pooled voting rights of the second to fifth largest shareholders to the voting rights of the largest shareholder (Attig et al. 2009; Luo et al. 2013).

Second, family involvement in management construct was measured by two items reflecting the construct: (i) the family CEO and (ii) the CEO-chairman's duality. This construct was used to reflect the preservation of the socioemotional wealth in family firms where the family had direct involvement in the firm's management (Berrone et al. 2012; Gomez-Mejia et al. 2011). Kowalewski et al. (2010) and Peng and Jiang (2010) suggest that family CEOs can be used to measure the degree of family involvement in management. The CEO-chairman's duality is also included because family firms may attempt to safeguard their family's interests by appointing family members as the CEO and Chairman of the board of directors (Tam and Tan 2007).

Third, capital structure, firms' investment, firms' size are included as controlling constructs. Capital structure was measured by two items: (i) the ratio of the total debt to the total assets and (ii) the ratio of the total debt to the total common shares (Luo et al. 2013; Chen et al. 2011). Likewise, the firms' investment construct was measured by two items: (i) the capital expenditure divided by the total assets and (ii) the capital expenditure di- 
vided by the total sales (King and Wen 2011; Cheng 2008). The firms' size (the book value of the firms' assets and the firms' sales) was included to control the economic advantages derived from the firms' resources (Demsetz and Lehn 1985).

Finally, year variables were included to control the time effects (Gutierrez and Pombo 2009). Because our sample period covers four years, three dummy variables $(2004,2005$ and 2006) were included whereas 2003 was excluded.

\section{Empirical Results and Discussions}

\section{Measurement Models}

Table 1 demonstrates the descriptive analysis for the observed variables in this study. The observed variables are the items that were measured by the constructs in the PLS-SEM. According to Hair et al. (2011), reflective measurement models in the PLS-SEM are assessed through indicator reliability, inter-

Table 1. Descriptive Statistics

\begin{tabular}{|c|c|c|c|}
\hline Constructs/indicators & Mean & Minimum & Maximum \\
\hline \multicolumn{4}{|l|}{ Firm performance } \\
\hline Market-to-book ratio & 0.71 & 0.10 & 7.29 \\
\hline \multicolumn{4}{|l|}{ Ownership concentration } \\
\hline Voting rights of the largest shareholder & 37.67 & 11.58 & 71.98 \\
\hline \multicolumn{4}{|l|}{ Family involvement in management } \\
\hline Family CEO & 0.73 & 0.00 & 1.00 \\
\hline CEO Duality & 0.37 & 0.00 & 1.00 \\
\hline \multicolumn{4}{|l|}{ Control contestability } \\
\hline $\begin{array}{l}\text { The ratio of the voting rights of the second } \\
\text { largest shareholder to the voting rights of } \\
\text { the largest shareholder }\end{array}$ & 0.31 & 0.01 & 1.00 \\
\hline $\begin{array}{l}\text { The ratio of the pooled voting rights of the } \\
\text { second to fifth largest shareholders to the } \\
\text { voting rights of the largest shareholder }\end{array}$ & 0.68 & 0.02 & 2.49 \\
\hline \multicolumn{4}{|l|}{ Board independence } \\
\hline $\begin{array}{l}\text { Proportion of independent directors on the } \\
\text { boards }\end{array}$ & 0.40 & 0.00 & 0.83 \\
\hline \multicolumn{4}{|l|}{ Capital structure } \\
\hline Ratio of total debt to total assets & 0.26 & 0.00 & 1.48 \\
\hline Ratio of total debt to total common shares & 0.65 & 0.00 & 14.86 \\
\hline \multicolumn{4}{|l|}{ Firm investment } \\
\hline Capital expenditure divided by total assets & 0.05 & 0.00 & 0.41 \\
\hline Capital expenditure divided by total sales & 0.08 & 0.00 & 1.09 \\
\hline \multicolumn{4}{|l|}{ Firm size } \\
\hline Firm assets (in RM million) & 286.57 & 12.74 & 3965.16 \\
\hline Sales (in RM million) & 336.54 & 24.40 & 3275.21 \\
\hline
\end{tabular}


nal consistency reliability, convergent validity and discriminant validity. Based on our analysis, all the indicator loadings in the reflective constructs achieved 0.743 and higher, which exceeds the minimum threshold value of 0.70 stipulated for the indicators' reliability (Hair et al. 2011) (see Table 2). Similarly, we noticed all the composite reliability results are higher than the minimum threshold value of 0.7 , which demonstrates all the construct measures achieved the required internal consistency reliability (Hair et al. 2011). The Average Variable Extracted (AVE) for all the constructs was 0.690 and higher, which exceeds the threshold value of 0.5 , providing evidence of convergent validity (Hair et al. 2011). Finally, we used Fornell-Larcker's criterion to assess the discriminant validity of the constructs. Our results show all the constructs have achieved discriminant validity because the square root of the AVEs was higher than all the inter-construct correlations (see Table 3) (Hair et al. 2011). In summary, our assessment shows that the measurement models in this study were reliable and valid.

\section{Table 2. Measurement Model Evaluation Results}

\begin{tabular}{|c|c|c|c|c|}
\hline Constructs/Indicators & Notation & Loading & $\begin{array}{l}\text { Composite } \\
\text { Reliability }\end{array}$ & AVE \\
\hline \multicolumn{5}{|l|}{ Firm performance } \\
\hline Market-to-book ratio & $\mathrm{MB}$ & 1 & 1 & 1 \\
\hline \multicolumn{5}{|l|}{ Ownership concentration } \\
\hline Voting rights of the largest shareholder & Conc & 1 & 1 & 1 \\
\hline \multicolumn{5}{|l|}{ Family involvement in management } \\
\hline Family CEO & FIM & 0.782 & 0.816 & 0.690 \\
\hline CEO Duality & & 0.877 & & \\
\hline \multicolumn{5}{|l|}{ Control contestability } \\
\hline $\begin{array}{l}\text { The ratio of the voting rights of the second largest } \\
\text { shareholder to the voting rights of the largest } \\
\text { shareholder }\end{array}$ & Contest & 0.977 & 0.981 & 0.963 \\
\hline $\begin{array}{l}\text { The ratio of the pooled voting rights of the second to } \\
\text { fifth largest shareholders to the voting rights of the } \\
\text { largest shareholder }\end{array}$ & & 0.985 & & \\
\hline Board independence & Bind & & & \\
\hline Proportion of independent directors on the boards & & 1 & 1 & 1 \\
\hline \multicolumn{5}{|l|}{ Capital structure } \\
\hline Ratio of total debt to total assets & Lev & 0.977 & 0.857 & 0.753 \\
\hline Ratio of total debt to total common shares & & 0.743 & & \\
\hline \multicolumn{5}{|l|}{ Firm investment } \\
\hline Capital expenditure divided by total assets & CAPEX & 0.946 & 0.950 & 0.905 \\
\hline Capital expenditure divided by total sales & & 0.957 & & \\
\hline \multicolumn{5}{|l|}{ Firm size } \\
\hline Firm assets & Size & 0.997 & 0.934 & 0.878 \\
\hline Sales & & 0.872 & & \\
\hline Year 2004 & 2004 & 1 & 1 & 1 \\
\hline Year 2005 & 2005 & 1 & 1 & 1 \\
\hline Year 2006 & 2006 & 1 & 1 & 1 \\
\hline
\end{tabular}


Gadjah Mada International Journal of Business - September-December, Vol. 17, No.3, 2015

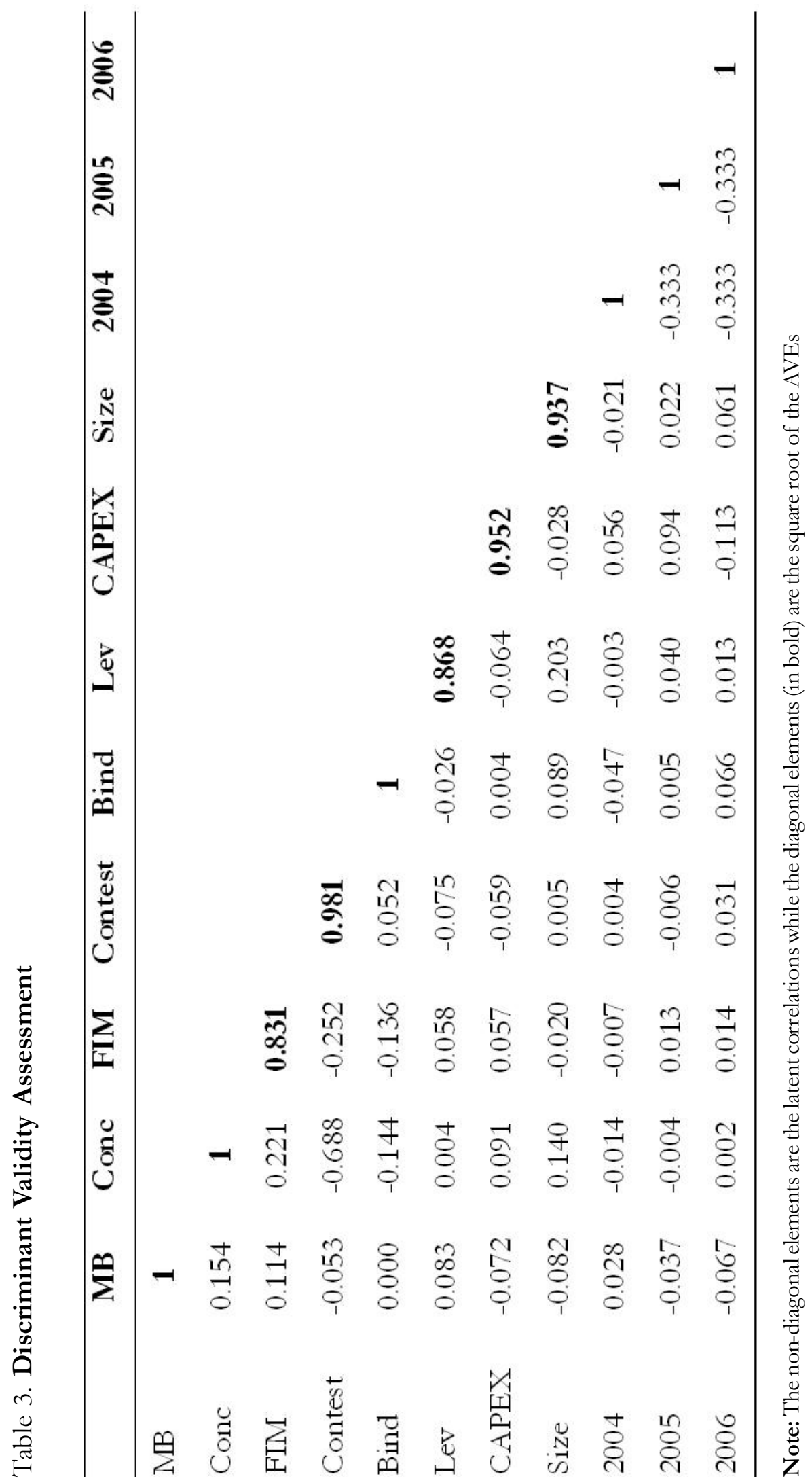




\section{Structural Model}

In estimating the significance level of the path coefficient, we used a bootstrapping procedure (448 cases and 5000 samples), a no-sign changes option and a path weighting scheme. The assessment of goodness-of-fit was not required in the structural model of the PLS-SEM (Chin 2010). Nevertheless, the model validity of the PLS-SEM was examined through a predictive relevance (Qsquared), to indicate the degree of predictive relevance at the indicator level, i.e., how well the model can sufficiently predict the indicators of the endogenous constructs (Hair, Ringle, and Sarstedt 2011). As a general rule of thumb, the predictive relevance must be greater than zero for the endogenous constructs in the model (Hair et al. 2011). In estimating the predictive relevance, we used a blindfolding procedure to obtain the QSquared of the endogenous constructs (Hair et al. 2011).

Figure 1 and Table 4 show the results of the structural model estimations without a mediator (i.e., control contestability).
Clearly, our results show that the predictive relevance (Q-squared) is above zero (i.e., 0.031), supporting the model's validity. Interestingly, our results show that family involvement in management has a positive and statistically significant $(p<0.01)$ relationship with the firms' performance (see Table IV), thus hypothesis $H_{1}$ is not supported. That is, our results show that the market exhibits a positive view of the Malaysian Chinese owner-managed firms, although corporate practitioners perceived that the expropriation of minority shareholders by the controlling shareholders is prevalent in Malaysia. This can be explained by the fact that strong control over their firms enable Malaysian Chinese family owners to be directly involved in such negotiations, and contract enforcement is weak in the Malaysian context because of the weak legal institutional settings (Claessens and Fan 2002). Thus, the positive impact of the aforementioned family involvement in management outweighs the appropriation concerns of the firms' resources in the Malaysian Chinese owner-managed firms.

Figure 1. Structural Model without Mediator (Model 1)

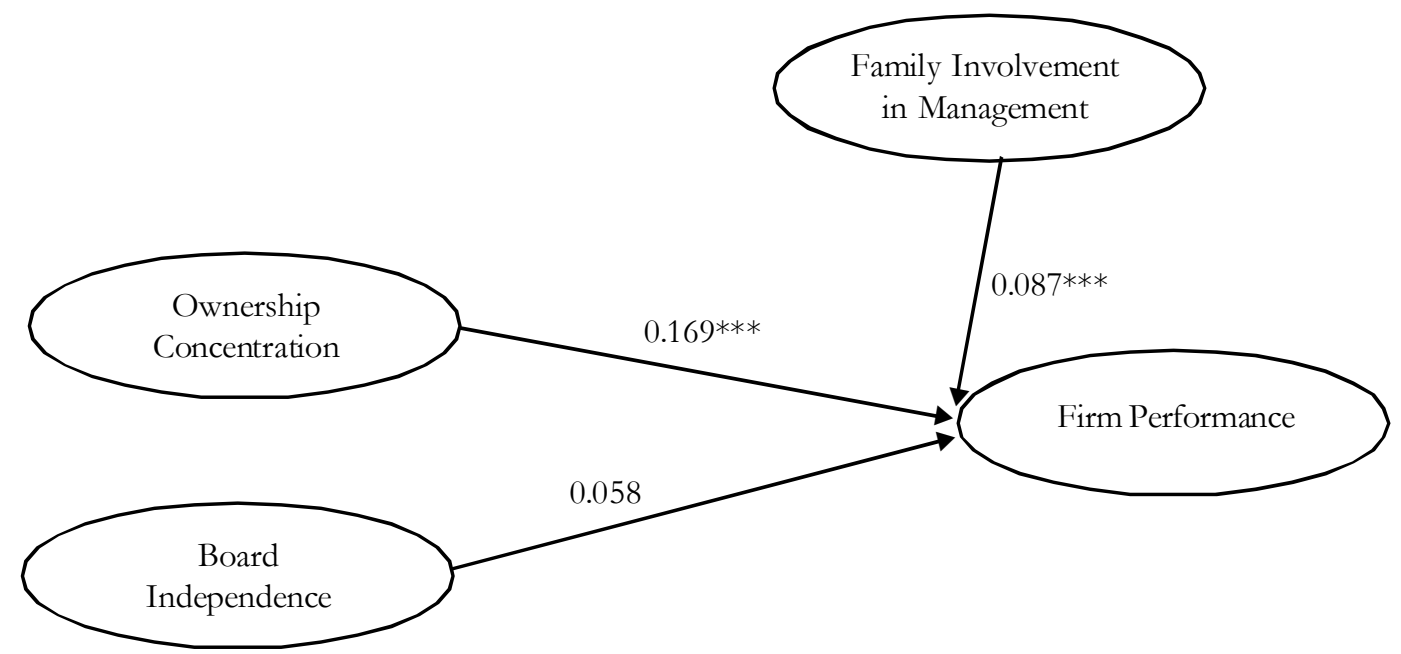

Note: $* * * / * * / *$ significant at the $0.01 / 0.05 / 0.10$ error level respectively; control variables are included but not presented in this figure 
Table 4. PLS Structural Model Results of Model 1 (without mediator)

\begin{tabular}{lccc}
\hline Endogenous Constructs & $\mathbf{R}^{\mathbf{2}}$ & & $\mathbf{Q}^{\mathbf{2}}$ \\
\hline $\mathrm{MB}$ & 0.071 & & 0.031 \\
\hline Relation & Path Coefficient & Std. Errors & t-Value \\
\hline Conc $\rightarrow \mathrm{MB}$ & $0.169^{* * *}$ & 0.040 & 4.252 \\
$\mathrm{FIM} \rightarrow \mathrm{MB}(\mathrm{H} 1)$ & $0.087^{* * *}$ & 0.033 & 2.616 \\
$\mathrm{Bind} \rightarrow \mathrm{MB}$ & 0.058 & 0.099 & 0.583 \\
$\mathrm{LEV} \rightarrow \mathrm{MB}$ & 0.103 & 0.063 & 1.632 \\
$\mathrm{CAPEX} \rightarrow \mathrm{MB}$ & $-0.093^{* * *}$ & 0.034 & 2.716 \\
Size $\rightarrow \mathrm{MB}$ & $-0.125^{* *}$ & 0.056 & 2.235 \\
\hline
\end{tabular}

Note: $* * * / * * / *$ denotes $1 \% / 5 \% / 10 \%$ error levels; year variables are included but not presented in the table.

Table 5 and Figure 2 show the results of the full path model with the mediator. The results show that the families' involvement in management has a negative and statistically significant relationship $(\phi<0.01)$ with control contestability (see Table 5), thus hypothesis $\mathrm{H}_{2}$ is supported. Additionally, control contestability in the ownership structure has a positive relationship $(p<0.01)$ with firms' performance.

With regard to the mediation analysis, we observed that the path coefficient of family involvement in management and firms' performance changes from $0.087(p<0.01)$ in Model 1 to $0.101(p<0.01)$ in Model 2. Following guidelines by Baron and Kenny (1986), we concluded that the control contestability exhibits a partial mediating role on the relationship between the families' involvement in management and their firms' performance. We also performed the Sobel test and found that the mediating effect of control contestability is statistical significance at the 1 percent error level (i.e., Sobel test-statistic $=-3.085$ ) and thus provided support for $H_{3}$ (see Table 6 ). Our results show that the indirect effects of family involvement in management on the firms' performance via the mediator construct (i.e., control contest- ability) is -0.045 whereas the total effects of family involvement in management on the firms' performance is 0.056 (see Table 6). These results support our contention that the non-dominant large shareholders suppress family orientations in the owner-managed firms. Family owners in owner-managed firms also tend to restrict the control contestability stemming from the non-dominant large shareholders to preserve their socioemotional wealth. However, the presence of non-dominant large shareholders can induce effective monitoring of the family owners in family firms.

Table 5 shows that the ownership concentration has a positive and statistically significant relationship $(p<0.01)$ with firms' performance. This result contradicts prior studies that used a broad-based sample (i.e., without distinguishing the ownership types) when investigating the relationship between the ownership concentration and firms' performance in Malaysia (Tam and Tan 2007; Liew et al. 2011). One explanation is that the ownership concentration is the main driver of Malaysian Chinese entrepreneurs to commit to family businesses because their wealth is linked to these firms' performance. On the other hand, our results indicate that board 
Figure 1. Structural Model without Mediator (Model 1)

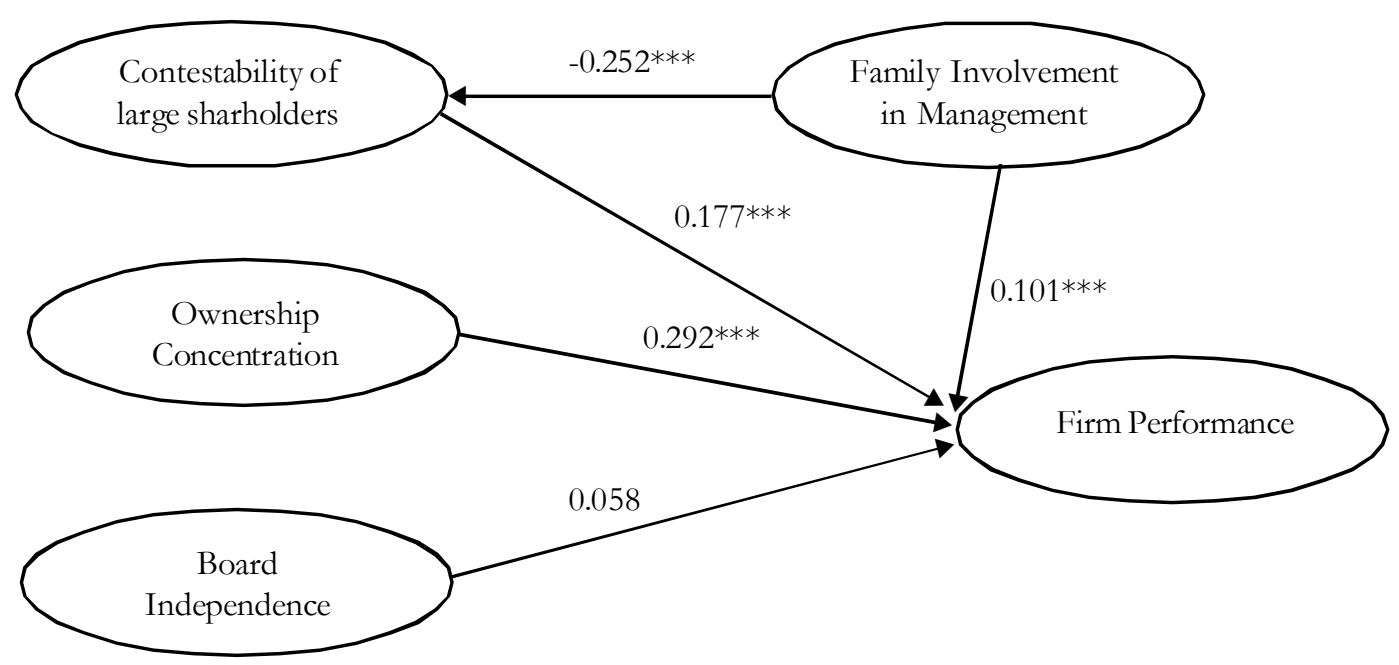

Note: $* * * / * * / *$ significant at the $0.01 / 0.05 / 0.10$ error level respectively; control variables are included but not presented in this figure

Table 5. PLS Structural Model Results of Model 2 (with mediator)

\begin{tabular}{lccc}
\hline Endogenous Constructs & $\mathbf{R}^{2}$ & & $\mathbf{Q}^{2}$ \\
\hline $\mathrm{MB}$ & 0.086 & & 0.046 \\
Contest & 0.063 & & 0.057 \\
\hline Relation & Path coefficient & Std. Error & t-Value \\
\hline Conc $\rightarrow$ MB & $0.292^{* * *}$ & 0.051 & 5.670 \\
FIM $\rightarrow$ Contest $(H 2)$ & $-0.252^{* * *}$ & 0.040 & 6.349 \\
FIM $\rightarrow$ MB (H1) & $0.101^{* * *}$ & 0.032 & 3.130 \\
Contest $\rightarrow$ MB & $0.177^{* * *}$ & 0.050 & 3.530 \\
Bind $\rightarrow$ MB & 0.070 & 0.098 & 0.719 \\
LEV $\rightarrow$ MB & $0.119^{*}$ & 0.064 & 1.862 \\
CAPEX $\rightarrow$ MB & $-0.095^{* * *}$ & 0.033 & 2.886 \\
Size $\rightarrow$ MB & $-0.147^{* *}$ & 0.059 & 2.501 \\
\hline
\end{tabular}

Note: $* * * * / * * / *$ denotes $1 \% / 5 \% / 10 \%$ error levels; year variables are included not presented in the table.

Table 6. Analysis of Mediating Effects

\begin{tabular}{cccc}
\hline \multirow{2}{*}{ Source Construct } & \multicolumn{3}{c}{ Target Construct = Firm Performance } \\
\cline { 2 - 4 } & Total Effect & Direct Effect & Indirect Effect \\
\hline Family involvement in management & 0.056 & 0.101 & -0.045 \\
\hline
\end{tabular}


independence yields a non-significant effect on the firms' performance. The findings could be attributed to the dominant position of the family owners, who regard outside directors as a source for advice and counselling, but not for monitoring. Additionally, independent directors may receive weak institutional support in performing their monitoring of the firms in Malaysia (Peng 2004; Porta et al. 1998).

The control variables show few interesting findings (see Table 5). The results suggest that the firms' investments have a negative and statistically significant relationship $(p<0.01)$ with the firms' performance, whereas the firms' leverage shows a positive and statistically significant $(p<0.10)$ relationship. In addition, the firms' size has a negative and statistically significant relationship $(p<0.05)$ with firms' performance. These results suggest that although investors are generally positive about the use of the firms' leverage in business operation, they are sceptical about management in regard to the firms' size (sales and assets) in Malaysian Chinese firms. One potential explanation is that bigger firm sizes may be attributed to the higher capital expenditure, which may not translate into higher profit margins. Malaysian Chinese entrepreneurs who emphasize the value of security may adopt conservative investment strategies in lowering the firms' investment risks rather than maximizing the firms' value (Au and Kwan 2009).

\section{Conclusion}

This paper explores how the preservation of socioemotional wealth can be manifested in the control and corporate governance of Malaysian Chinese firms. The findings are as follows. First, we showed that family involvement in management exhibits a positive relationship with the firms' performance. Second, control contestability stemming from non-dominant large shareholders mediates the relationship between the families' involvement in management and the firms' performance. Third, the market perceives non-dominant large shareholders as a monitoring mechanism of family controlling shareholders in Malaysian Chinese firms. Overall, we show that Malaysian Chinese entrepreneurs prioritize their control in ownermanaged firms because they want to preserve their socioemotional wealth. We interpret that Malaysian Chinese entrepreneurs, who operate under a hostile business environment, prioritize their control of their firms. Thus, 'life-raft' values' are still held by Malaysian Chinese entrepreneurs in owner-managed firms.

This paper makes three contributions to the literature. First, it sheds light on how socioemotional wealth can be manifested in the control and corporate governance of firms in a transition economy. Because the socioemotional wealth in family firms has been largely studied in advanced economies, it may be interesting to explore this issue in emerging economies with hostile business environments in state-directed economies. Specifically, socioemotional wealth suggests family owners prioritize their families' interests, but we found that the benefits of family involvement in management outweighed the appropriation concerns of the firms' resources in Malaysian Chinese owner-managed firms.

Second, we provide evidence that ingrained 'life-raft values' among overseas Chinese entrepreneurs can be associated with the preservation of their socioemotional wealth. Stated differently, this study represents the first attempt to offer the linkage between socioemotional wealth and 'life-raft values' in overseas Chinese family businesses. 
Third, this study represents the first attempt to show that control contestability mediates the relationship between family involvement in management and firms' performance.

Finally, this study was to some extent limited by the hostile business context for Malaysian Chinese family firms. It is conceivable to suggest that family businesses are af- fected by institutional environments and cultures with regard to the preservation of socioemotional wealth. Future research can be extended to family businesses in other emerging and advanced economies to investigate the reactions of family owners in response to the threat of non-dominant large shareholders to their control of their firms.

\section{Acknowledgement}

We thank the anonymous reviewers for their constructive comments.

\section{Reference}

Adams, R. B., B. E. Hermalin, and M. S. Weisbach. 2010. The role of boards of directors in corporate governance: A conceptual framework and survey. Journal of Economic Literature 48 (1): 58-107.

Attig, N., S. El Ghoul, and O. Guedhami. 2009. Do multiple large shareholders play a corporate governance role? Evidence from East Asia. Journal of Financial Research 32 (4): 395-422.

Au, K., and H. K. Kwan. 2009. Start-up capital and Chinese entrepreneurs: The role of family. Entrepreneurship Theory and Practice 33 (4): 889-908.

Azim, M.I. 2012. Corporate governance mechanisms and their impact on company performance: A structural equation model analysis. Australian Journal of Management 37 (3): 481-505.

Baron, R.M., and D.A. Kenny. 1986. The moderator-mediator variable distinction in social psychological research: Conceptual, strategic, and statistical considerations. Journal of personality and social psychology 51 (6): 1173-1182.

Berrone, P., C. Cruz, and L.R. Gomez-Mejia. 2012. Socioemotional wealth in family firms: Theoretical dimensions, assessment approaches, and agenda for future research. Family Business Review 25 (3): 258-279.

Berthelot, S., C. Francoeur, and R. Labelle. 2012. Corporate governance mechanisms, accounting results and stock valuation in Canada. International Journal of Managerial Finance 8 (4): 332-343.

Bertrand, M., and A. Schoar. 2006. The role of family in family firms. The Journal of Economic Perspectives 20 (2): 73-96.

Burkart, M., D. Gromb, and F. Panunzi. 1998. Why higher takeover premia protect minority shareholders. Journal of Political Economy 106 (1): 172-204.

Business, T. 2013. Bright packaging showdown to take place today. 21 Feb, available at: http:/ / wnw.btimes.com.my/Current_News/BTIMES/articles/BPI20/_Article/ (accessed 1 March 2013).

Carney, M., and E. Gedajlovic. 2002. The co-evolution of institutional environments and organizational strategies: The rise of family business groups in the ASEAN region. Organization Studies 23 (1): 129.

Carney, R. W., and T. B. Child. 2013. Changes to the ownership and control of East Asian corporations between 1996 and 2008: The primacy of politics. Journal of Financial Economics 107 (2): 494-513. 
Chen, D., M. Jian, and M. Xu. 2009. Dividends for tunneling in a regulated economy: The case of China. Pacific-Basin Finance Journal 17 (2): 209-223.

Chen, V., J. Li, and D. Shapiro. 2011. Are OECD-prescribed "good corporate governance practices" really good in an emerging economy? Asia Pacific Journal of Management 28 (1): 115-138.

Cheng, S. 2008. Board size and the variability of corporate performance. Journal of Financial Economics 87 (1): 157-176.

Chin, W.W. 2010. How to write up and report PLS analyses. Handbook of Partial Least Squares (pp. 655690). Heidelberg: Springer Berlin.

Claessens, S., and J. P. H. Fan. 2002. Corporate governance in Asia: A survey. International Revien of Finance 3 (2): 71-103.

Claessens, S., D. Simeon, J. P. H. Fan, and L. H. P. Lang. 2002. Disentangling the incentive and entrenchment effects of large shareholdings. The Journal of Finance 57 (6): 2741-2771.

Daily, C. M., and J. L. Johnson. 1997. Sources of CEO power and firm financial performance: A longitudinal assessment. Journal of Management 23 (2): 97-117.

Demsetz, H., and K. Lehn. 1985. The structure of corporate ownership: Causes and consequences. The Journal of Political Economy 93 (0): 1155-1177.

Diamantopoulos, A., M. Sarstedt, C. Fuchs, P. Wilczynski, and S. Kaiser. 2012. Guidelines for choosing between multi-item and single-item scales for construct measurement: A predictive validity perspective. Journal of the Academy of Marketing Science 40 (3): 434-449.

Dyer, W. G. 2003. The family: The missing variable in organizational research. Entrepreneurship Theory and Practice 27 (4): 401-416.

Finkelstein, S. 1992. Power in top management teams: Dimensions, measurement, and validation. The Academy of Management Journal 35 (3): 505-538.

Friedman, E., S. Johnson, and T. Mitton. 2003. Propping and tunneling. Journal of Comparative Economics 31 (4): 732-750.

Gassen, J. (2014). Causal inference in empirical archival financial accounting research. Accounting, Organizations and Society 39 (7): 535-544.

Goh, C.F., S.-U.-R. Khan, and A. Rasli. 2014. CEO duality, board independence, corporate governance and firm performance in family firms: Evidence from the manufacturing industry in Malaysia. Asian Business \& Management 13 (4): 333-357.

Gomez-Mejia, L.R., C. Cruz, P. Berrone, and J. De Castro. 2011. The bind that ties: Socioemotional wealth preservation in family firms. The Academy of Management Annals 5 (1): 653-707.

Gómez-Mejía, L.R., K.T. Haynes, M. Núñez-Nickel, K.J.L. Jacobson, and J. Moyano-Fuentes. 2007. Socioemotional wealth and business risks in family-controlled firms: Evidence from Spanish olive oil mills. Administrative Science Quarterly 52 (1): 106-137.

Gomez-Mejia, L.R., M. Larraza-Kintana, and M. Makri. 2003. The determinants of executive compensation in family-controlled public corporations. The Academy of Management Journal 46 (2): 226-237.

Gomez, E.T. 2009. The rise and fall of capital: Corporate Malaysia in historical perspective. Journal of Contemporary Asia 39 (3): 345-381.

Grosfeld, I. 2009. Large shareholders and firm value: Are high-tech firms different? Economic Systems 33 (3): 259-277. 
Gutierrez, L.H., and C. Pombo. 2009. Corporate ownership and control contestability in emerging markets: The case of Colombia. Journal of Economics and Business 61 (2): 112-139.

Hair, J.F., C.M. Ringle, and M. Sarstedt. 2011. PLS-SEM: Indeed a silver bullet. The Journal of Marketing Theory and Practice 19 (2): 139-152.

He, J., and H. C. Wang. 2009. Innovative knowledge assets and economic performance: The asymmetric roles of incentives and monitoring. The Academy of Management Journal 52 (5): 919-938.

Jiang, Y., and M. Peng. 2011. Principal-principal conflicts during crisis. Asia Pacific Journal of Management 28 (4): 683-695.

Johnson, R.A., and D.W. Greening. 1999. The effects of corporate governance and institutional ownership types on corporate social performance. The Academy of Management Journal 42 (5): 564-576.

Jones, C.D., M. Makri, and L.R. Gomez-Mejia. 2008. Affiliate directors and perceived risk bearing in publicly traded, family-controlled firms: The case of diversification. Entrepreneurship Theory and Practice 32 (6): 1007-1026.

Kao, J. 1993. The worldwide web of Chinese business. Harvard business review 71 (2): 24-33.

King, T.-H.D., and M.-M. Wen. 2011. Shareholder governance, bondholder governance, and managerial risk-taking. Journal of Banking \& Finance 35 (3): 512-531.

Kor, Y.Y. 2006. Direct and interaction effects of top management team and board compositions on R\&D investment strategy. Strategic Management Journal 27 (11): 1081-1099.

Kowalewski, O., O. Talavera, and I. Stetsyuk. 2010. Influence of family involvement in management and ownership on firm performance: Evidence from Poland. Family Business Review 23 (1): 45-59.

La Porta, R., F. Lopez-de-Silanes, A. Shleifer, and R. Vishny. 2002. Investor protection and corporate valuation. Journal of Finance LVII (3): 1147-1170.

Le, S.A., B. Walters, and M. Kroll. 2006. The moderating effects of external monitors on the relationship between R\&D spending and firm performance. Journal of Business Research 59 (2): 278-287.

Li, J., K. Lam, G. Qian, and Y. Fang. 2006. The effects of institutional ownership on corporate governance and performance: An empirical assessment in Hong Kong. Management International Review 46 (3): 259-276.

Liew, C.Y., F.A. Samad, S.a. Munir, and E. Alfan. 2011. Expropriation-related variables \& firm performance: Evidence from Malaysian family firms. available at: http: //ssrn.com/abstract $=1874592$ or bttp: //dx.doi.org/10.2139/ssrn.1874592 (accessed 12 April 2012).

Liew, P.K. 2007. Corporate governance reforms in Malaysia: The key leading players' perspectives. Corporate Governance: An International Review 15 (5): 724-740.

Lin, Y.-F. 2005. Corporate governance, leadership structure and CEO compensation: Evidence from Taiwan. Corporate Governance: An International Review 13 (6): 824-835.

Luo, J-h., D-f. Wan, D. Cai, and H. Liu. 2013. Multiple large shareholder structure and governance: The role of shareholder numbers, contest for control, and formal institutions in chinese family firms. Management and Organization Review 9 (2): 265-294.

Mace, M. L. 1972. The president and the board of directors. Harvard Business Review 50 (2): 37-49.

Miller, D., I. Le Breton-Miller, and R.H. Lester. 2011. Family and lone founder ownership and strategic behaviour: Social context, identity, and institutional logics. Journal of Management Studies 48 (1): 1-25.

Peng, M. W. 2004. Outside directors and firm performance during institutional transitions. Strategic Management Journal 25 (5): 453-471. 
Peng, M. W., and Y. Jiang. 2010. Institutions behind family ownership and control in large firms. Journal of Management Studies 47 (2): 253-273.

Porta, R. L., F. Lopez-de-Silanes, and A. Shleifer. 1999. Corporate ownership around the world. The Journal of Finance 54 (2): 471-517.

Porta, R. L., F. L-d. Silanes, A. Shleifer, and R.W. Vishny. 1998. Law and finance. Journal of Political Economy 106 (6): 1113-1155.

Ringle, C., S. Wende, and A. Will. 2005. Smartpls 2.0. In University of Hamburg.

Saffi, P. A. C., and K. Sigurdsson. 2011. Price efficiency and short selling. Review of Financial Studies 24 (3): 821-852.

Schulze, W. S., and E. R. Gedajlovic. 2010. Whither family business? Journal of Management Studies 47 (2): 191-204.

Shanker, M. C., and J. H. Astrachan. 1996. Myths and realities: Family businesses' contribution to the US economy - a framework for assessing family business statistics. Family Business Review 9 (2): 107123.

Shleifer, A., and R. W. Vishny. 1986. Large shareholders and corporate control. Journal of Political Economy 94 (3): 461-488.

Siebels, J.-F., and D. zu Knyphausen-Aufseß. 2012. A review of theory in family business research: The implications for corporate governance. International Journal of Management Reviews 14 (3): 280-304.

Sirmon, D. G., and M. A. Hitt. 2003. Managing resources: Linking unique resources, management, and wealth creation in family firms. Entrepreneurship Theory and Practice 27 (4): 339-358.

Tam, O. K., and M.G-S. Tan. 2007. Ownership, governance and firm performance in Malaysia. Corporate Governance: An International Review 15 (2): 208-222.

Wahab, E. A. A., H. Haron, C. L. Lok, and S. Yahya. 2011. Does corporate governance matter? Evidence from related party transactions in Malaysia. In International corporate governance (advances in financial economics), edited by J. Kose, M. Anil and P. F. Stephen. United Kingdom: Emerald Group Publishing Limited.

Wijaya, Y. 2008. The prospect of familism in the global era: A study on the recent development of the ethnic-Chinese business, with particular attention to the Indonesian context. Journal of Business Ethics 79 (3): 311-317.

Yasuda, N. 1991. Malaysian's new economic policy and the industrial co-ordination act. The Developing Economies 29 (4): 330-349.

Yeung, H. W-c. 1999. Under siegs? Economic globalization and Chinese business in Southeast asia. Economy and Society 28 (1): 1-29.

Young, M. N., M. W. Peng, D. Ahlstrom, G.D. Bruton, and Y. Jiang. 2008. Corporate governance in emerging economies: A review of the principal-principal perspective. Journal of Management Studies 45 (1): 196-220.

Zellweger, T. M., F. W. Kellermanns, J. J. Chrisman, and J. H. Chua. 2012. Family control and family firm valuation by family CEOs: The importance of intentions for transgenerational control. Organization Science 23 (3): 851-868. 